Agnieszka Rybka

\title{
OCCUPATIONAL HEARING LOSS IN PODKARPACKIE VOIVODESHIP AND IN POLAND BETWEEN THE YEARS 2008-2017
}

\author{
ZAWODOWE USZKODZENIE SŁUCHU W WOJEWÓDZTWIE PODKARPACKIM \\ I W POLSCE W LATACH 2008-2017
}

Provincial Sanitary Inspectorate in Rzeszów

Wojewódzka Stacja Sanitarno-Epidemiologiczna w Rzeszowie

ABSTRACT

INTRODUCTION. Among the population of adults, hearing loss related to occupational exposure to noise makes up ca 16\%, which is the second etiological factor, after ageing, causing anomalies connected with hearing. According to statistical data, in Europe about 30 million of employees are exposed to the noise. In Poland the number equals to 187500 .

AIM. The analysis of the structure of confirmed cases of occupational hearing loss between 2008-2017 in Poland and in Podkarpackie Voivodeship.

METERIALS AND METHODS. Information related to Podkarpackie Voivodeship was obtained out of the cards verifying occupational illness, sent by National Sanitary District Inspectors from particular districts of Podkarpackie Voivodship to Podkarpacki National Provincial Sanitary Inspectorate. The data related to Poland within indicated period of time are obtained out of the studies entitled Occupational illnesses in Poland, published by Occupational Health Institute in Łódź.

RESULTS. In Poland double permanent hearing loss is decreasing. In Podkarpackie Voivodship, during the analysed period of time, the incidence of recognition of occupational hearing loss was not high, a total of 74 cases, including 1 case when the illness concerned a woman. In most cases the occupational hearing loss caused by the noise in Poland and in Podkarpackie Voivodship was revealed in industrial processing.

CONCLUSIONS. Most cases of occupational hearing loss in Poland was diagnosed with the men over 60 years old in Śląskie and Pomorskie Voivodeship, professionally linked to mining, heavy mechanical and metallurgical industry as well as means of transport. In Podkarpackie Voivodeship the increased number of diagnosed cases revealed in districts: stalowowolski, krośnieński, rzeszowski and przemyski (metallurgical and timber industry).

Key words: noise, job-related illnesses, epidemiology

\section{STRESZCZENIE}

WSTĘP. W populacji osób dorosłych ok. 16\% stanowią uszkodzenia słuchu powiązane z ekspozycją zawodową na hałas, który jest drugim po procesie starzenia się czynnikiem etiologicznym nieprawidłowości związanych ze słuchem. W Europie według danych statystycznych ok. 30 milionów pracowników jest narażonych na hałas - w Polsce liczba ta wynosi 187,5 tysięcy osób.

CEL PRACY. Analiza struktury stwierdzonych przypadków zawodowego uszkodzenia słuchu w latach 20082017 w Polsce i w województwie podkarpackim.

MATERIAL I METODY. Informacje odnoszące się do województwa podkarpackiego zostały pozyskane z kart weryfikujących chorobę zawodową, wysyłanych do Podkarpackiego Państwowego Wojewódzkiego Inspektora Sanitarnego przez Państwowych Powiatowych Inspektorów Sanitarnych poszczególnych powiatów województwa podkarpackiego. Dane dotyczące Polski w omawianym czasookresie uzyskane są z wydawanych przez Instytut Medycyny Pracy w Łodzi opracowań pt. Choroby zawodowe w Polsce.

WYNIKI. W Polsce obustronny trwały ubytek słuchu systematycznie zmniejsza się. W województwie podkarpackim w analizowanym okresie czasu częstość rozpoznawania zawodowego uszkodzenia słuchu była niewiel-

$\overline{0 \text { c National Institute of Public Health - National Institute of Hygiene / Narodowy Instytut Zdrowia Publicznego - Państwowy Zakład Higieny }}$ 
ka łącznie 74 przypadki, w tym w 1 przypadku chorobę tą rozpoznano u kobiety. Zdecydowaną większość przypadków zawodowego uszkodzenia słuchu spowodowanego hałasem w Polsce i w województwie podkarpackim stwierdzono w przetwórstwie przemysłowym.

WNIOSKI. Najwięcej przypadków zawodowego uszkodzenia słuchu w Polsce stwierdzono u mężczyzn po 60. roku życia w województwach: śląskim i pomorskim, związanych zawodowo z górnictwem, przemysłem ciężkim - maszynowym, hutnictwem i środkami transportu. W województwie podkarpackim zwiększoną liczbę przypadków stwierdzono w powiatach: stalowowolskim, krośnieńskim, rzeszowskim i przemyskim (przemysł hutniczy i drzewny).

Słowa kluczowe: hałas, choroby zawodowe, epidemiologia.

\section{INTRODUCTION}

Among the population of adults, hearing loss related to job-related exposure to noise makes up ca $16 \%$, which is the second etiological factor, after ageing, causing anomalies connected with hearing. (1)

According to statistical data, in Europe about 30 million of employees are exposed to the noise (2). In Poland the number equals to 187500 employees (3).

Until 1995 job-related hearing loss made up the greatest proportion of all diagnosed occupational illnesses, and currently it comes fifth among these illnesses. Job-related hearing loss comes before such illnesses as: infectious and parasitic diseases, pneumoconiosis, chronic diseases of larynx, chronic peripheral nervous system diseases (4).

Occupational exposure to the noise in a workplace, in case of exceeding the acceptable noise level with simultaneous lack of prophylactic measures, may lead to irreversible and incurable disease symptoms (2).

The effect of the long-term exposure to the noise is progressive sensorineural hearing loss. Moreover, it can extra auditory disorders, which increases the risk of such diseases as: coronary disease, arterial hypertension, tachycardia, neurotic disorders, sleep and hormonal disorders (2).

In work environment noise has different levels of acoustic pressure, which changes in time (5). Hearing loss caused by exposure to the noise during first years of work concerns mainly 4-6 kHz frequency. Hearing loss due to 3 and $2 \mathrm{kHz}$ appears within further period of exposure. Changes in deterioration of acoustic organ's function which equal to or are higher than $10 \mathrm{~dB}$ on average for frequencies 2, 3 and $4 \mathrm{kHz}$, can be acknowledged as crucial progression of hearing loss, which eventually may lead to serious deterioration of acoustic organ's function (6).

Hearing loss largely depends on: duration of the exposure, range of noise frequency, noise intensity, character of exposure to sharp or persistent noise, individual vulnerability to noise, lack of ear protection (7). It is worth mentioning, that acoustic energy absorbed by the acoustic organ is much more harmful in case of permanent exposure to the noise. The same amount of energy interrupted by breaks results in smaller hearing loss (8).

\section{WSTĘP}

W populacji osób dorosłych ok. 16\% stanowią uszkodzenia słuchu powiązane z ekspozycją zawodową na hałas, który jest drugim po procesie starzenia się czynnikiem etiologicznym nieprawidłowości związanych ze słuchem (1).

W Europie według danych statystycznych ok. 30 milionów pracowników jest narażonych na hałas (2) - w Polsce liczba ta wynosi ok. 187,5 tysiąca osób (3). Wśród wszystkich stwierdzonych chorób zawodowych, zawodowe uszkodzenie słuchu do roku 1995 określało największy ich odsetek (2). Obecnie schorzenie to znajduje się na 5 miejscu wykazu chorób zawodowych. Występuje przed takimi jednostkami chorobowymi jak: choroby zakaźne lub pasożytnicze, pylice płuc, przewlekłe choroby narządu głosu, przewlekłe choroby obwodowego układu nerwowego (4).

Ekspozycja zawodowa na hałas w miejscu pracy w przypadku poziomów przekraczających dopuszczalne normy, przy braku odpowiednich działań profilaktycznych, może prowadzić do nieodwracalnych i nieuleczalnych zmian chorobowych (2).

Efektem przewlekłego działania hałasu jest postępujący niedosłuch odbiorczy. Ponadto może on powodować skutki pozasłuchowe, zwiększając ryzyko wystąpienia takich zaburzeń zdrowia, jak: choroba wieńcowa, nadciśnienie tętnicze, tachykardia, zespoły nerwicowe, zaburzenia snu i hormonalne (2).

W środowisku pracy hałas cechuje różny poziom ciśnienia akustycznego, który zmienia się w czasie (5). Uszkodzenie słuchu spowodowane narażeniem na hałas w pierwszych latach pracy dotyczy głównie częstotliwości 4-6 kHz. Częstotliwości 3 i $2 \mathrm{kHz}$ występują $\mathrm{w}$ dalszym okresie narażenia. Zmiany równe lub większe niż $10 \mathrm{~dB}$ średnio dla częstotliwości 2, 3 i $4 \mathrm{kHz}$ można uznać za istotną progresję uszkodzenia słuchu, która może w ostateczności doprowadzić do poważnego pogorszenia funkcji narządu słuchu (6).

Uszkodzenie słuchu w dużej mierze zależy od: czasu trwania narażenia, zakresu częstotliwości hałasu, intensywności hałasu, charakteru ekspozycji na hałas ostrego bądź przewlekłego, indywidualnej podatności na działanie hałasu, braku używania ochronników słuchu (7). Należy nadmienić, że energia akustyczna absorbowana przez narząd słuchu jest zdecydowanie bardziej 
Among ontogenic factors, which increase the risk of hearing loss there are the following factors: age, complexion, sex, cigarettes smoking, chronic metabolic illnesses, general health condition of the employee, used ototoxic medicines (cytostatic drugs, aminoglycoside antibiotics), organic dissolvent (toluene, styrene, carbon disulphide), pesticides, heavy metals (7).

The existing in working environment values (the highest recommended exposure to physical factors harmful to health in working environment, established as exposure levels according to the features of particular factors which affect the employee during his professional activity should not cause negative changes in his health condition and in health condition of his future generations) as well as threshold values of their activity, make up the criterion for the assessment of employee's exposure to the noise in a workplace $(9,10)$. The noise level intensity in Poland in relations to 8-hours working time $\left(\mathrm{L}_{\mathrm{EX}, 8 \mathrm{~h}}\right)$ or one week working time cannot exceed the value of $85 \mathrm{~dB}$. For the maximum level of $A$ sound $\left(\mathrm{L}_{\mathrm{Amax}}\right)$ the value equals to $115 \mathrm{~dB}$, while for the utmost sound level $\mathrm{C}\left(\mathrm{L}_{\text {Cpeak }}\right)$ it is $135 \mathrm{~dB}(10)$. In case of exceeding $\mathrm{L}_{\mathrm{EX}, 8 \mathrm{~h}}-80 \mathrm{~dB}$ the employer should provide the employees with ear protection, however the employees are not obliged to apply the recommendations. If $\mathrm{L}_{\mathrm{EX}, 8 \mathrm{~h}}-85 \mathrm{~dB}$ are exceeded the employer obliges the employees to use ear protection and also introduces a complex programme of ear protection to the employees (11).

The contraindication to practice of a profession when exposed to the noise can be acoustic organ diseases, e.g.: permanent receptive displacement of hearing threshold over the value emerging from the process of aging, head injury with permanent hearing loss, incurable middle ear outflow or surgery operations, Meniere's disease and other middle ear diseases (12).

For the purpose of deciding upon job-related hearing loss, occupational health uses subjective tests such as pure tone audiogram, which measures hearing thresholds for frequency band $125 \mathrm{~Hz}-8 \mathrm{kHz}$. Low frequencies include the band between $125 \mathrm{~Hz}$ and $500 \mathrm{~Hz}$, medium frequencies between 1 and $2 \mathrm{kHz}$, high frequencies over $2 \mathrm{kHz}$ (13). In order to distinguish between cochlear and retrocochlear hearing loss supraliminal examination is conducted (including SISI test). Moreover, in occupational health objective tests, which do not require the cooperation with the examined person, are used: otoacoustic emissions and auditory brainstem responses - ABR. In addition, otoacoustic emissions are used for prophylaxis of hearing loss as they allow for monitoring early hearing loss (13).

\section{THE AIM}

The analysis of the structure of diagnosed cases of job-related hearing loss between 2008 and 2017 in Poland and Podkarpackie Voivodeship. szkodliwa w przypadku ciągłego oddziaływania hałasu. Taka sama ilość energii rozdzielona przerwami skutkuje mniejszym uszkodzeniem narządu słuchu (8).

Wśród czynników osobniczych, zwiększających ryzyko uszkodzenia słuchu należy wymienić: wiek, karnację, płeć, palenie papierosów, przewlekłe choroby metaboliczne, ogólny stan zdrowia pracownika, stosowane leki ototoksyczne (cytostatyki, antybiotyki aminoglikozydowe), rozpuszczalniki organiczne (toluen, styren, dwusiarczek węgla), pestycydy, metale ciężkie (7).

Występujące $\mathrm{w}$ środowisku pracy wartości NDN (najwyższych dopuszczalnych natężeń fizycznych czynników szkodliwych dla zdrowia w środowisku pracy, ustalone jako poziomy ekspozycji odpowiednio do właściwości poszczególnych czynników, których oddziaływanie na pracownika w okresie jego aktywności zawodowej nie powinno spowodować ujemnych zmian w jego stanie zdrowia oraz $w$ stanie zdrowia jego przyszłych pokoleń) oraz wartości progowe ich działania stanowią kryterium oceny narażenia pracownika na hałas w miejscu pracy $(9,10)$. Dopuszczalna wartość hałasu w Polsce w odniesieniu do 8-godzinnego dobowego wymiaru czasu pracy $\left(\mathrm{L}_{\mathrm{EX}, 8 \mathrm{~h})}\right.$ lub tygodniowego czasu pracy nie może przekraczać wartości $85 \mathrm{~dB}$. Dla maksymalnego poziomu dźwięku $\mathrm{A}\left(\mathrm{L}_{\mathrm{Amax}}\right)$ wartość ta wynosi $115 \mathrm{~dB}$, a dla szczytowego poziomu dźwięku C ( $\left.\mathrm{L}_{\text {Cpeak }}\right) 135 \mathrm{~dB}$ (10).

W przypadku przekroczenia $\mathrm{L}_{\mathrm{EX}, 8 \mathrm{~h}}-80 \mathrm{~dB}$ pracodawca powinien udostępnić pracownikom możliwość korzystania z ochronników słuchu, przy czym pracownicy nie muszą stosować się do jego zaleceń. Jeżeli przekroczone są $\mathrm{L}_{\mathrm{EX}, 8 \mathrm{~h}}-85 \mathrm{~dB}$ pracodawca zobowiązuje pracowników do obowiązkowego korzystania z ochronników słuchu ponadto wdraża w życie kompleksowy program ochrony słuchu u zatrudnionych osób (11).

Przeciwwskazaniem do wykonywania pracy w ekspozycji na hałas mogą być choroby narządu słuchu np.: odbiorcze trwałe przesunięcie progu słuchu powyżej wartości wynikających z procesu starzenia się, uraz głowy z trwałą utratą słuchu, wyciek z ucha środkowego niepoddający się leczeniu lub przebyte operacje, choroba Ménière'a i inne choroby ucha wewnętrznego (12).

Przy orzekaniu o zawodowym uszkodzeniu słuchu w medycynie pracy wykorzystuje się badania subiektywne jak audiogram tonalny, w którym mierzone są progi słuchu dla częstotliwości z pasma $125 \mathrm{~Hz}-8 \mathrm{kHz}$. Częstotliwości niskie obejmują pasmo od $125 \mathrm{~Hz}$ do $500 \mathrm{~Hz}$, średnie od 1 do $2 \mathrm{kHz}$, wysokie powyżej $2 \mathrm{kHz}$ (13). W celu odróżnienia uszkodzenia ślimakowego i pozaślimakowego słuchu wykonuje się badania nadprogowe (m.in. próbę SISI). W medycynie pracy wykorzystuje się ponadto badania obiektywne, niewymagające współpracy osoby badanej jak emisje otoakustyczne oraz słuchowe potencjały wywołane z pnia mózgu (auditory brainstem responses ABR). Dodatkowo emisje otoakustyczne wykorzystywane są w profilaktyce uszkodzeń słuchu ponieważ pozwalają monitorować wczesne uszkodzenia słuchu (13). 


\section{MATERIAL AND METHODS}

The subject of the analysis of diagnosed cases of jobrelated hearing loss in Podkarpackie Voivodship between 2008 -2017 are cards, which verify the occupational illness, and which are sent to Podkarpacki State Provincial Sanitary Inspectorate (PPWIS) by State District Sanitary Inspectors from particular districts of Podkarpackie Voivodeship (14). The analysis of cases of job-related hearing loss diagnosed in Poland were obtained from the studies entitled "Jobrelated illnesses in Poland", published by the Occupational Health Institute (IMP) in Łódź (4, 15-23).

The criterion for the analysis of job-related hearing loss in Podkarpackie Voivodship and in Poland was done according to the scheme of Polish Activity Classification - PKD (24). The analysis of the level of morbidity to job-related hearing loss in Podkarpackie Voivodeship was conducted by means of absolute numbers as well as the morbidity rate for 100000 employed in section C industrial processing. The data related to the number of persons employed in the conditions exposing to noise, were collected from the Central Statistics Office (3).

\section{RESULTS}

\section{Data for the whole Poland}

Between 2008-2017 a total number of 2045 cases of job-related hearing loss were diagnosed in Poland. Within the analysed period of time this illness appeared in a prevalent number in men $(98.4 \%)$ and stayed at similar level except the year 2010 (331 cases). Since 2011 the number of these illnesses was regularly decreasing (Fig. 1).

\section{CEL PRACY}

Analiza struktury stwierdzonych przypadków zawodowego uszkodzenia słuchu w latach 2008-2017 w Polsce i w województwie podkarpackim.

\section{MATERIAŁ I METODY}

Przedmiotem analizy stwierdzonych przypadków zawodowego uszkodzenia słuchu w województwie podkarpackim w latach 2008-2017 są karty weryfikujące chorobę zawodową, które wysyłane są do Podkarpackiego Państwowego Wojewódzkiego Inspektora Sanitarnego (PPWIS) przez Państwowych Powiatowych Inspektorów Sanitarnych poszczególnych powiatów województwa podkarpackiego (14). Analizy przypadków zawodowego uszkodzenia słuchu stwierdzonych w Polsce pozyskano z opracowań wydawanych przez Instytut Medycyny Pracy (IMP) w Lodzi pt. Choroby zawodowe w Polsce (4, 15-23).

Kryterium analizy zawodowego uszkodzenia słuchu w województwie podkarpackim i Polsce dokonano według schematu Polskiej Klasyfikacji Działalności - PKD (24).

Analiza poziomu zachorowalności zawodowego uszkodzenia słuchu w województwie podkarpackim została przeprowadzona za pomocą liczb bezwzględnych oraz współczynnika zachorowalności na 100000 zatrudnionych w sekcji C - przetwórstwo przemysłowe. Dane odnośnie ilości osób zatrudnionych w warunkach narażenia na hałas pozyskano z Głównego Urzędu Statystycznego (3).

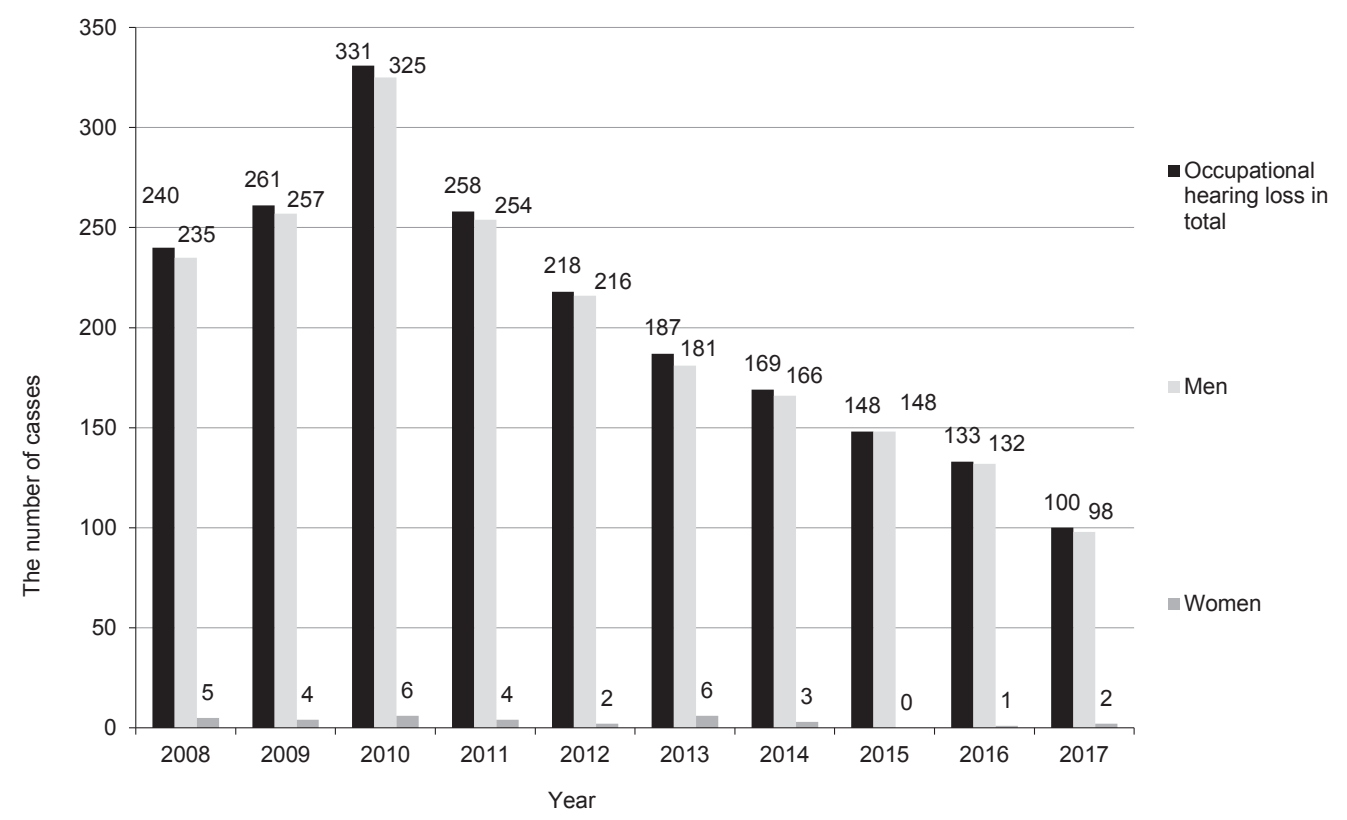

Fig. 1. The number of verified cases of occupational hearing damage for women and men in Poland between 2008-2017 $(4,15-23)$.

Ryc. 1. Liczba stwierdzonych przypadków zawodowego uszkodzenia słuchu u kobiet i mężczyzn w Polsce w latach 2008-2017 (4, 15-23). 
Between 2008-2017 in Poland job-related hearing loss in most cases was diagnosed for people over 40 years old. The most cases were diagnosed among people over 60 years old while this illness was not diagnosed among people younger than 29. In each age group men prevailed (Tab. IA, Tab. IB).

In Poland it was observed that the number of cases of occupational illnesses after 10-14 years of employment when exposed to the noise is increasing. The most cases were reported after the period of exposure equalled to or was higher than 20 years of employment. The least cases of job-related hearing loss were reported after 1-4 yeras of employment when exposed to the noise (Tab. II).

\section{WYNIKI}

\section{Dane dla calej Polski}

W latach 2008-2017 w Polsce stwierdzono ogółem 2045 przypadków zawodowego uszkodzenia słuchu. $\mathrm{W}$ analizowanym okresie czasu schorzenie to występowało w przeważającej liczbie u mężczyzn $(98,4 \%)$ i utrzymywało się na zbliżonym poziomie za wyjątkiem roku 2010 (331 przypadków). Od roku 2011 liczba tych chorób systematycznie zmniejsza się (Ryc. 1).

W latach 2008-2017 w Polsce zawodowe uszkodzenie słuchu orzekano w większości przypadków u osób po 40 roku życia. Najwięcej przypadków odnotowano u osób po 60 roku życia, a wśród osób poniżej 29 roku życia nie stwierdzono tej jednostki chorobowej. W każdej grupie wiekowej dominowali mężczyźni (Tab. IA, Tab. IB).

Table IA. The number of cases of occupational hearing loss in Poland between 2008 and 2010 according to age group and sex (15-17)

Tabela IA. Liczba przypadków zawodowego uszkodzenia słuchu w Polsce w latach 2008-2010 według grup wiekowych i płci (15-17)

\begin{tabular}{|c|c|c|c|c|c|c|c|}
\hline \multicolumn{8}{|c|}{ Age groups } \\
\hline \multirow{7}{*}{ Year } & & & $\leq 29$ & $30-39$ & $40-49$ & $50-59$ & $60 \geq$ \\
\hline & \multirow{2}{*}{2008} & Women & 0 & 0 & $1(20 \%)$ & $3960 \%)$ & $1(20 \%)$ \\
\hline & & Men & 0 & $2(0.8 \%)$ & $38(16.2 \%)$ & $137(58.3 \%)$ & $58(24.7 \%)$ \\
\hline & \multirow{2}{*}{2009} & Women & 0 & 0 & $1(25 \%)$ & $2(50 \%)$ & $1(25 \%)$ \\
\hline & & Men & 0 & $3(1.2 \%)$ & $24(9.3 \%)$ & $151(58.7 \%)$ & $79(30.7 \%)$ \\
\hline & \multirow{2}{*}{2010} & Women & 0 & 0 & $1(16.7 \%)$ & $4(66.6 \%)$ & $1(16.7 \%)$ \\
\hline & & Men & 0 & $1(0.3 \%)$ & $31(9.5 \%)$ & $163(50.2 \%)$ & $130(40 \%)$ \\
\hline \multirow{3}{*}{\multicolumn{2}{|c|}{ Total including: }} & Total & 0 & $6(0.7 \%)$ & $96(11.5 \%)$ & $460(55.3 \%)$ & $270(32.4 \%)$ \\
\hline & & Women & 0 & $6(28.6 \%)$ & $3(14.3 \%)$ & $9(42.8 \%)$ & $3(14.3 \%)$ \\
\hline & & Men & 0 & 0 & $93(11.5 \%)$ & $451(55.6 \%)$ & $267(32.9 \%)$ \\
\hline
\end{tabular}

Table IB. The number of cases of occupational hearing loss in Poland between 2011 and 2017 according to age group and sex $(4,18-23)$

Tabela IB. Liczba przypadków zawodowego uszkodzenia słuchu w Polsce w latach 2011-2017 według grup wiekowych i płci $(4,18-23)$

\begin{tabular}{|c|c|c|c|c|c|c|c|c|c|}
\hline \multicolumn{10}{|c|}{ Age groups } \\
\hline \multirow{15}{*}{ Year } & & & $\leq 24$ & $25-34$ & $35-44$ & $45-54$ & $55-59$ & $60-64$ & $\geq 65$ \\
\hline & \multirow{2}{*}{2011} & Women & 0 & 0 & $1(25 \%)$ & $1(25 \%)$ & $1(25 \%)$ & $1(25 \%)$ & 0 \\
\hline & & Men & 0 & 0 & $5(2 \%)$ & $52(20.5 \%)$ & $73(28.7 \%)$ & $112(44.1 \%)$ & $12(4.7 \%)$ \\
\hline & \multirow{2}{*}{2012} & Women & 0 & 0 & 0 & 0 & $2(100 \%)$ & 0 & 0 \\
\hline & & Men & 0 & 0 & $2(0.9 \%)$ & $44(20.4 \%)$ & $59(27.3 \%)$ & $101(47.8 \%)$ & $10(4.6 \%)$ \\
\hline & \multirow{2}{*}{2013} & Women & 0 & 0 & $1(16.7 \%)$ & $2(33.3 \%)$ & $3(50 \%)$ & 0 & 0 \\
\hline & & Men & 0 & 0 & 0 & $26(14.4 \%)$ & $45(24.9 \%)$ & $94(51.9 \%)$ & $16(8.8 \%)$ \\
\hline & \multirow{2}{*}{2014} & Women & 0 & 0 & 0 & $1(33.3 \%)$ & $1(33.3 \%)$ & $1(33.3 \%)$ & 0 \\
\hline & & Men & 0 & 0 & $2(1.2 \%)$ & $29(17.5 \%)$ & $37(22.3 \%)$ & $84(50.6 \%)$ & $14(8.4 \%)$ \\
\hline & \multirow{2}{*}{2015} & Women & 0 & 0 & 0 & 0 & 0 & 0 & 0 \\
\hline & & Men & 0 & 0 & $1(0.7 \%)$ & $22(14.0 \%)$ & $28(18.9 \%)$ & $80(54 \%)$ & $17(11.4 \%)$ \\
\hline & \multirow{2}{*}{2016} & Women & 0 & 0 & 0 & 0 & $1(100 \%)$ & 0 & 0 \\
\hline & & Men & 0 & 0 & $1(0.7 \%)$ & $20(15.1 \%)$ & $17(12.9 \%)$ & $77(58.4 \%)$ & $17(12.9 \%)$ \\
\hline & \multirow{2}{*}{2017} & Women & 0 & 0 & 0 & 0 & 0 & $2(100 \%)$ & 0 \\
\hline & & Men & 0 & 0 & $1(1 \%)$ & $10(10.2 \%)$ & $11(11.2 \%)$ & $54(55.1 \%)$ & $22(22.5 \%)$ \\
\hline \multirow{3}{*}{\multicolumn{2}{|c|}{ Total including: }} & Total & 0 & 0 & $14(1.2 \%)$ & $207(17 \%)$ & $278(22.9 \%)$ & $606(49.9 \%)$ & $108(8.9 \%)$ \\
\hline & & Women & 0 & 0 & $2(11.2 \%)$ & $4(22.2 \%)$ & $8(44.4 \%)$ & $4(22.2 \%)$ & 0 \\
\hline & & Men & 0 & 0 & $12(1 \%)$ & $203(17 \%)$ & $270(22.6 \%)$ & $602(50.4 \%)$ & $108(9 \%)$ \\
\hline
\end{tabular}


Part of the occurrence of job-related hearing loss in particular voivodships between 2008-2017 was varied. The analysis showed that the highest number of cases of job-related hearing loss apperared in Śląskie and Pomorskie Voivodship. Smaller number of these illnesses was noted in Wielkopolskie, Zachodniopomorskie, Małopolskie, Świętokrzyskie, Dolnośląskie and Kujawsko-Pomorskie Voivodship. The least cases were observed in Podlaskie, Łódzkie and Warmńsko-Mazurskie Voivodship. Some cases of job-related hearing loss were also reported outside Polish borders (Fig. 2).

According to the section and activity of PKD (Polish Activity Classification) permanent bilateral cochlear hearing loss caused by the noise, appeared mostly in industry. The total number of cases in that section reached 1168 , including $15.3 \%$ related to metal production department (179 cases). In next positions there is mining and extraction with a total number of 431 cases, then construction - 163 cases. In transportation and storage economy 117 cases were noted $(4,15-23)$.
W Polsce zauważano zwiększającą się liczbę przypadków chorób zawodowych po 10-14 latach pracy w narażeniu na hałas. Najwięcej przypadków odnotowano po okresie narażenia równym lub większym niż 20 lat pracy. Najmniej przypadków zawodowego uszkodzenia słuchu odnotowano po 1-4 lat pracy w narażeniu na hałas (Tab. II).

Częstość występowania zawodowego uszkodzenie słuchu w poszczególnych województwach w latach 20082017 była zróżnicowana. Analiza wykazała największą liczbę przypadków zawodowego uszkodzenia słuchu w województwach: śląskim i pomorskim. Mniejszą częstość tych chorób w liczbach bezwzględnych odnotowano w województwach: wielkopolskim, zachodniopomorskim, małopolskim, świętokrzyskim, dolnośląskim oraz kujawsko-pomorskim. Najmniej przypadków natomiast odnotowano w województwach: podlaskim, łódzkim i warmińsko-mazurskimi. Kilka przypadków zawodowego uszkodzenia słuchu stwierdzono u pracowników pracujących poza granicami Polski (Ryc. 2).

Table II. The number of cases of occupational hearing loss for women and men in Poland between 2008-2017 vs the period of exposure to noise $(4,15-23)$

Tabela II. Liczba przypadków zawodowego uszkodzenia słuchu w Polsce w latach 2008-2017 a okres narażenia na hałas (4,15-23)

\begin{tabular}{|c|c|c|c|c|c|}
\hline \multicolumn{7}{|c|}{ The period of exposure in given years } \\
\hline Year & $1-4$ & $5-9$ & $10-14$ & $15-19$ & $\geq 20$ \\
\hline 2008 & $1(0.4 \%)$ & $6(2.5 \%)$ & $8(3.3 \%)$ & $17(7.1 \%)$ & $208(86.7 \%)$ \\
\hline 2009 & 0 & $4(1.6 \%)$ & $5(1.9 \%)$ & $11(4.2 \%)$ & $241(92.3 \%)$ \\
\hline 2010 & 0 & $2(0.6 \%)$ & $10(3 \%)$ & $13(3.9 \%)$ & $306(92.5 \%)$ \\
\hline 2011 & 0 & $4(1.6 \%)$ & $7(2.7 \%)$ & $22(8.5 \%)$ & $225(87.2 \%)$ \\
\hline 2012 & $1(0.5 \%)$ & $1(0.5 \%)$ & $6(2.7 \%)$ & $10(4.6 \%)$ & $200(91.7 \%)$ \\
\hline 2013 & $3(1.7 \%)$ & $4(2.1 \%)$ & $6(3.2 \%)$ & $7(3.7 \%)$ & $167(89.3 \%)$ \\
\hline 2014 & 0 & $2(1.2 \%)$ & $4(2.4 \%)$ & $11(6.6 \%)$ & $152(89.9 \%)$ \\
\hline 2015 & 0 & $1(0.7 \%)$ & $3(2 \%)$ & $4(2.7 \%)$ & $140(94.6 \%)$ \\
\hline 2016 & $1(0.7 \%)$ & 0 & $4(3 \%)$ & $7(5.3 \%)$ & $121(91 \%)$ \\
\hline 2017 & 0 & $3(3 \%)$ & $1(1 \%)$ & $4(4 \%)$ & $92(92 \%)$ \\
\hline Total & $6(0.3 \%)$ & $27(1.3 \%)$ & $54(2.6 \%)$ & $106(5.2 \%)$ & $1852(90.6 \%)$ \\
\hline
\end{tabular}

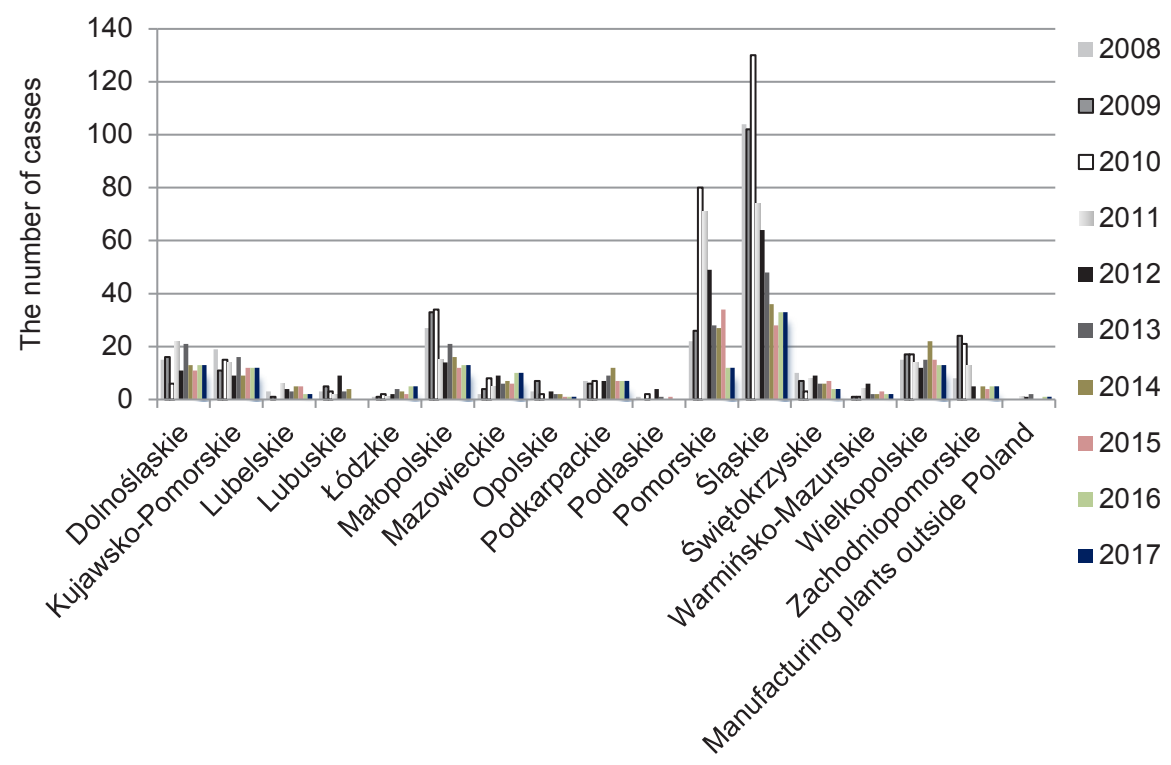

Fig. 2. The number of cases of occupational hearing damage in particular voivodeships between 2008-2017 (4, 15-23)

Ryc. 2. Liczba przypadków zawodowego uszkodzenia słuchu w poszczególnych województwach w latach 2008-2017 (4, 15-23) 


\section{Data for the Podkarpackie Voivodeship}

In Podkarpackie Voivodeship between 2008-2017 74 cases of job-related hearing loss were diagnosed. The most cases were noted in 2011 ( 11 cases) and 2014 (12 cases), the least i.e. 2 cases were noted in 2017 (Fig. 3). The number of persons employed on positions exposed to the noise was from 127011 employees in 2012 up to 174741 in 2017. In other years the number of people working in exposure to the noise stayed at similar lever i.e. about 130000 (3). The morbidity factor defying the number of cases of job-related hearing loss in Podkarpackie Voivodeship for 100000 employed in industrial processing between 2008-2017 was placed between 1,1 in 2017 up to 9.1 in 2014. In majority of analysed time this factor was at similar level from 4.2 in 2016 up to 5.3 in 2010 (3).

The Podkarpackie Voivodeship districts with high numbers of diagnosed cases of the $\mathrm{a} / \mathrm{m}$ occupational hearing loss are: Stalowowolski District (23 cases), Przemyski District (12 case), Krośnieński District (11 cases) and Rzeszowski District (10 cases). Respectively, in each of 12 districts 1 case was diagnosed or none (Fig. 3).

Between 2008-2017 in Podkarpackie Voivodeship for 74 diagnosed cases only 1 case of diagnosed occupational hearing loss was related to a woman. Persons' age: from 43 to 79 . In vast majority the illness was diagnosed for persons older than 50 years old, most of which was noted for men older than 60 years old. The period of time of exposure to the noise was between 8-44 years (14). In 3 cases the occupational illness was recognised as a consequence of exposure to the noise though the period of time not exceeding 10 working years. The diagnosed illnesses appeared for men aged 47, 57 and 68 in Stalowowolski, Przemyski and Sanocki Distrcict. In all cases the occupational illness was recognised in section $\mathrm{C}$ - industrial processing. In one case the time periods of exposure to escessive noise were separated by 9 -year periods without exposure, and in two cases they were continuous (14). Vast majority of the cases of job-related hearing loss caused by the noise were recognised in section C - industrial processing (59), including 16 cases in division 28 - machines and devices manufacturing, not classified anywhere else. The remaining cases of job-related hearing loss were recognised in sections: $\mathrm{B}$ - mining and extraction (4 cases), D - production and supply of electric energy, gas, steam, hot water air for air conditioning systems (2), F - construction (2), G - wholesale and retail trade; vehicles repairs including motorcycles (2), $\mathrm{H}-$ transportation and storage economy (4), Q - healthcare and social service (1) (14).
W latach 2008-2017 według sekcji i działalności PKD obustronny trwały ubytek słuchu typu ślimakowego spowodowany hałasem występował w przeważającej ilości w branży przemysłowej. Łączna liczba przypadków w tej sekcji sięgnęła 1168 , z tego $15,3 \%$ wykazano w dziale produkcja metali (179 przypadków). Na kolejnych pozycjach znalazło się górnictwo i wydobycie z łączną liczbą przypadków 431, budownictwo - 163 przypadki. W dziale transport i gospodarka magazynowa odnotowano 117 przypadków $(4,15-23)$.

\section{Dane dla województwa podkarpackiego}

W województwie podkarpackim w latach 20082017 łącznie stwierdzono 74 przypadki zawodowego uszkodzenia słuchu. Najwięcej przypadków odnotowano w roku 2011 (11 przypadków) i 2014 (12 przypadków), najmniej 2 przypadki w 2017 roku (Ryc. 3). Liczba zatrudnionych na stanowiskach pracy, gdzie stwierdzono narażenie na hałas wynosiła od 127011 osób w roku 2012 do 174741 w 2017. W pozostałych latach liczba osób pracujących w ekspozycji na hałas utrzymywała się na zbliżonym poziomie ok. 130000 (3). Współczynnik zachorowalności określający liczbę przypadków zawodowego uszkodzenia słuchu w województwie podkarpackim na 100000 zatrudnionych w przetwórstwie przemysłowym w latach 2008-2017 mieścił się w granicach od 1,1 w 2017 roku do 9,1 w 2014 roku. W większości analizowanego czasu współczynnik ten był na zbliżonym poziomie od 4,2 w roku 2016 do 5,3 w roku 2010 (3).

Powiatami województwa podkarpackiego o znacznej liczbie stwierdzonych przypadków w/w choroby zawodowego uszkodzenia słuchu są: stalowowolski (23 przypadki), przemyski (12 przypadków), krośnieński (11 przypadków) i rzeszowski (10 przypadków). Odpowiednio w 12 powiatach stwierdzono po 1 przypadku lub wcale (Ryc. 3).

W latach 2008-2017 w województwie podkarpackim na 74 stwierdzonych przypadków tylko 1 przypadek zawodowego uszkodzenia słuchu stwierdzono u kobiety. Wiek osób: od 43 do 79 lat. W przeważającej większości w/w choroba zawodowa pojawiła się u osób powyżej 50 roku życia, a najwięcej przypadków odnotowano u mężczyzn po 60 roku życia. Okres czasu narażenia na hałas mieścił się w przedziale od 8 do 44 lat (14). W 3 przypadkach chorobę zawodową rozpoznano jako następstwo narażenia na hałas przez okres nie przekraczający 10 lat pracy. Stwierdzone choroby wystąpily u mężczyzn w wieku 47, 57 i 68 lat $\mathrm{w}$ powiatach stalowowolskim, przemyskim i sanockim. We wszystkich przypadkach chorobę zawodową stwierdzono w sekcji C - przetwórstwo przemysłowe. 
Fig. 3. The number of cases of occupational hearing damage in particular districts of Podkarpackie voivodeship between 2008-2017 (14)

Ryc. 3. Liczba przypadków zawodowego uszkodzenia słuchu w poszczególnych powiatach województwa podkarpackiego w latach 2008-2017 (14)

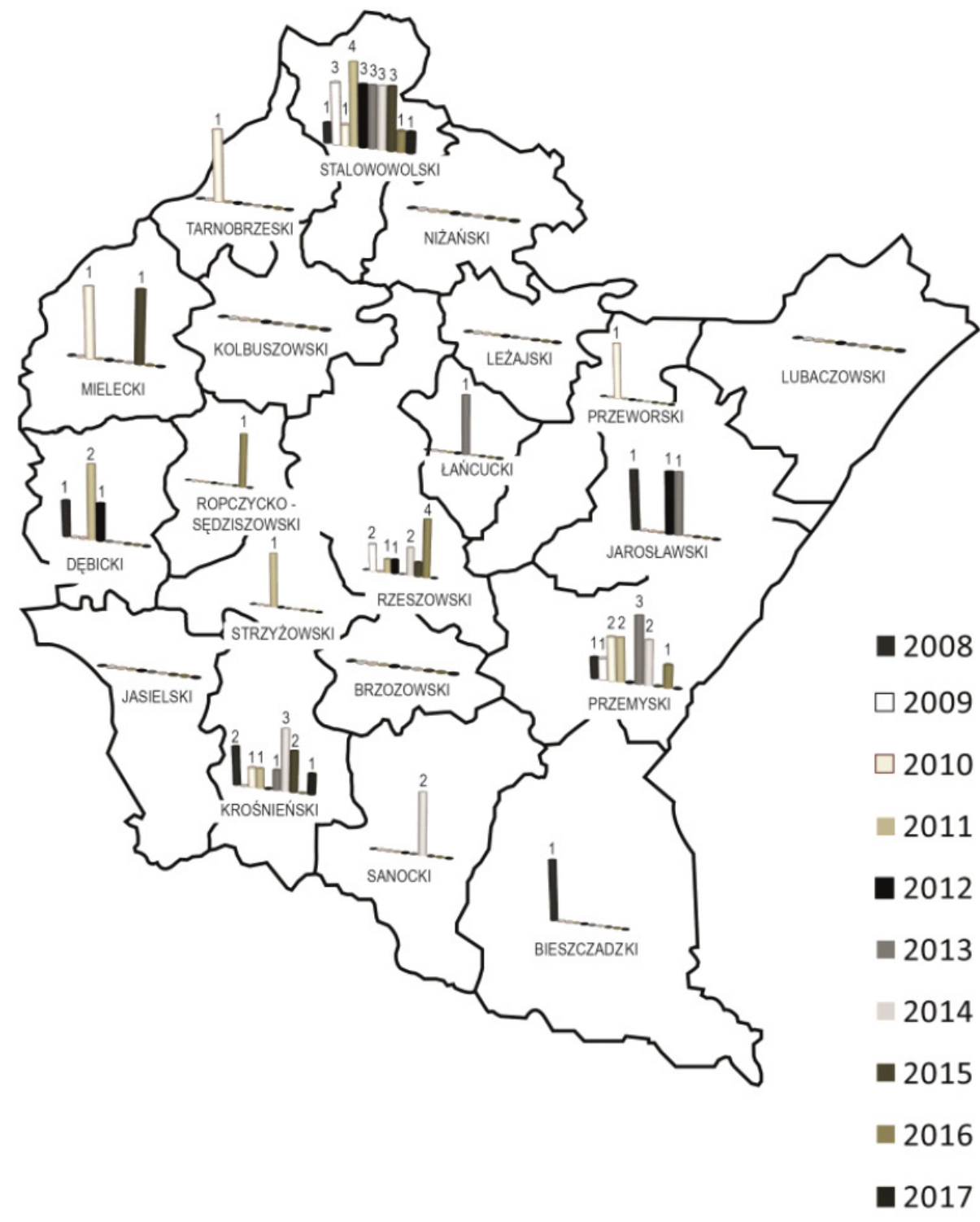

\section{DISCUSSION}

The number of job-related hearing loss cases in Polish population is increasing in the last years.

The data from the Occupational Health Institute (IMP) in Łódź and the Provincial Sanitary Inspectorate (WSSE) in Rzeszów lead straight to the conclusion, that the majority of the $\mathrm{a} / \mathrm{m}$ occupational illnesses was recognised for men aged over 60 . The reason for that could be longterm period of exposure to the noise, which with age increased the hearing loss, as well as the fact, that the employees who get retired are not afraid to have the occupational illness diagnosed at the moment they would not lose their job.

The correlation between the hearing loss and a longterm exposure to the noise was observed by Agarwal G. and others, who in the years 2011-2013
W 1 przypadku okresy pracy w narażeniu na nadmierny hałas rozdzielone były 9-letnim czasem pracy bez narażenia, w pozostałych 2 przypadkach były ciągłe (14). Zdecydowaną większość przypadków uszkodzenia słuchu spowodowanego hałasem stwierdzono w sekcji C - przetwórstwo przemysłowe (59), w tym 16 przypadków w dziale 28 - produkcja maszyn i urządzeń gdzie indziej niesklasyfikowanych. Pozostałe przypadki zawodowego uszkodzenia słuchu stwierdzono w sekcjach: B - górnictwo i wydobycie (4 przypadki), D wytwarzanie i zaopatrywanie w energię elektryczną, gaz, parę wodną, gorącą wodę i powietrze do układów klimatyzacyjnych (2), F - budownictwo (2), G - handel hurtowy i detaliczny; naprawa pojazdów samochodowych, włączając motocykle (2), H - transport i gospodarka magazynowa (4), Q - opieka zdrowotna i pomoc społeczna (1) (14). 
carried out the studies of evaluation of hearing in a steel factory, located near the village hospital, among 350 employees with the job seniority of at least 5 years and more. The results of their studies show, that 235 employees were exposed to the noise for 16 to 20 years time. Among the employees with such job seniority 7 had medium hearing loss diagnosed in a right ear, while 8 in a left ear (25).

A small number of diagnosed cases of hearing loss for women results from the fact, that the $\mathrm{a} / \mathrm{m}$ occupational illnesses appears in sections and activities of PKD (Polish Activity Classification) where majority of the working staff are men. In Poland few women work in professions related to industrial processing, construction, transportation and storage economy (26).

Among the companies, where workers are diagnosed predominantly with permanent bilateral cochlear hearing loss, are coal mines (8). In Polish mining hearing loss takes the second place among occupational illnesses (27). This illness is also related to the workers employed in heavy industry, construction, textile industry as well as machines and devices mechanics (8). The voivodeships with the highest number of diagnosed occupational hearing loss are: Śląskie and Pomorskie Voivodeship. This results from high industrialization of these voivodeships, where noise as a harmful factor is present. The increase in the number of cases of hearing loss in heavy industry was also observed by Rangkooy H.A. and others in the study carried out in 2016 among 34 workers from different professional groups in Kavian Steel Company. The studies proved that the hearing loss caused by the noise was the highest for welders and machining workstation (28). Verbeek J.H. and others came to the conclusion, that the hearing loss cause by the noise at work was the problem of industrialized countries. Lower exposure to the noise was achieved thanks to realization of the programme of hearing loss prevention, especially by the use of ear protectors which dampen the noise (29).

A high number of cases in voivodeships: Wielkopolskie, Zachodniopomorskie, Małopolskie, Świętokrzyskie, Dolnośląskie and KujawskoPomorskie Voivodeship can be related to wide industrial infrastructure. Analogously, a small number of cases in Podlaskie and Warmińsko-Mazurskie Voivodeship does not surprise due to a small number number of industrial works there. However, the results from Łódzkie Voivodeship may come surprising as there are many workers employed in industry with few recognised cased. Such results may be caused by underestimation of occupational illnesses being the result of workers' fear of loosing their job or being relegated to other, less rewarding, job position. In Poland the tendency of increasing the number of occupational hearing loss illnesses is also related to the closure of particular

\section{DYSKUSJA}

Znaczny wzrost zawodowego uszkodzenia słuchu w roku 2010 można przypisać ogólnej tendencji zwiększenia się liczby przypadków chorób zawodowych stwierdzonych w latach 2008-2017 (Ryc. 1).

Z danych $z$ IMP $w$ Łodzi i WSSE w Rzeszowie wynika wprost, że zdecydowaną większość w/w choroby zawodowej stwierdzono u mężczyzn po 60. roku życia. Przyczyną tego może być wieloletni okres narażenia na hałas, który wraz z wiekiem spotęgował ubytek słuchu, jak również dochodzenie ustalenia choroby zawodowej w momencie odchodzenia na emeryturę, gdy pracownicy nie obawiają się już o utratę zatrudnienia.

Korelację pomiędzy ubytkiem słuchu a wieloletnim narażeniem na hałas zauważyli Agarwal G. i wsp., którzy w latach 2011-2013 przeprowadzili badania oceny stanu słuchu w fabryce stali znajdującej się w pobliżu wiejskiego szpitala wśród 350 pracowników ze stażem pracy co najmniej 5 lat i więcej. Z ich badania wynika, że 235 pracowników było narażonych na hałas przez okres czasu od 16 do 20 lat. Wśród pracowników z takim stażem pracy u 7 stwierdzono umiarkowaną utratę słuchu w uchu prawym, natomiast w uchu lewym u 8 (25).

Niewielka liczba stwierdzonych ubytków słuchu u kobiet wynika z faktu występowania w/w choroby zawodowej w sekcjach i działalnościach PKD, gdzie zdecydowana większość kadry pracowniczej stanowią mężczyźni. W Polsce mało kobiet pracuje w zawodach: modelarza w drewnie, hutnika, szlifierza, spawacza, czy ślusarza.

Wśród przedsiębiorstw, w których dominuje u pracownika stwierdzony trwały obustronny ubytek słuchu typu ślimakowego są kopalnie węgla kamiennego (8). W polskim górnictwie wśród chorób zawodowych uszkodzenie słuchu od dekady zajmuje drugie miejsce (26). Choroba ta dotyczy również pracowników zatrudnionych w zakładach przemysłu ciężkiego, budowlanych, przemysłu włókienniczego oraz mechaników maszyn i urządzeń (8).

Znaczny wzrost stwierdzonych przypadków zawodowego uszkodzenia słuchu jest odzwierciedleniem obecności czynnika szkodliwego - hałasu w zróżnicowanych gałęziach gospodarki, zwłaszcza przemysłu ciężkiego w województwie śląskim i pomorskim. Wzrost przypadków ubytku słuchu w przemyśle ciężkim zaobserwowali również Rangkooy H.A. i wsp., w swoim badaniu przeprowadzonym w 2016 roku wśród 34 pracowników w różnych grupach zawodowych w firmie Kavian Steel Company. W swoich badaniach dowiedli, że ubytek słuchu spowodowany hałasem był największy u spawaczy i na stanowisku obróbki skrawaniem (27). 
industrial works in PKD (Polish Activity Classification) sectors, where the employees were exposed to excessive noise (30). In Podkarpackie Voivodeship the employees from the so called "industrialized" districts distiguished themselves by a high number of cases of hearing loss (Stalowowolski, Krośnieński and Rzeszowski District). A bigger number of cases of job-related hearing loss in Przemyski District has its explanation in specific economy of this district, where wood industry creates the risk of higher exposure to the noise. A small number of cases of occupational hearing loss for employees in other districts can be caused by underestimation of occupational illnesses. Moreover, the small number of the cases also results from preventive measures of security and occupational hygiene service as well as the supervising institutions such as State Sanitary Inspection and State Labour Inspection.

\section{CONCLUSIONS}

1. Since 2010 in Poland it is observed that the number of cases of occupational hearing loss is constantly decreasing.

2. This illness is most often recognised for men aged over 60 , professionally related to mining and heavy industry - machines, metallurgy and means of transport.

3. Śląskie and Pomorskie Voivodeships have the highest absolute number of diagnosed cases of hearing loss with occupational aetiology.

4. The incidence of recognition of job-related hearing loss in Podkarpackie voivodeship is small. Between 2008-2017 74 cases of that illness were recognised.

5. In Podkarpackie Voivodeship the districts with the highest number of cases of occupational hearing loss are: Stalowowolski (metallurgy), Krośnieński, Rzeszowski and Przemyski District (metallurgy and wood industry).

6. The differentiation of appearance of job-related hearing loss in Podkarpackie Voivodeship comes out of its infrastructure. In most districts there are not many industrial works with excessive exposure to the noise.

\section{REFERENCES}

1. Śliwińska-Kowalska M. Wprowadzenie W: Profilaktyka zawodowych uszkodzeń słuchu. Poradnik dla lekarzy, red. M. Śliwińska-Kowalska Wydaw. Instytut Medycyny Pracy, Łódź 2010: 5.

2. Śliwińska-Kowalska M. Wpływ hałasu na zdrowie W: Minimalizowanie ryzyka uszkodzenia słuchu w miejscu pracy. Poradnik dla pracowników BHP, PIS, PIP, pracodawców i pracowników, red. M. Pawlaczyk-Łuszczyńska, Wydaw. Instytut Medycyny Pracy, Łódź 2010: 9-12.
Verbeek J.H. i wsp., wywnioskowali, że ubytek słuchu spowodowany hałasem w miejscu pracy był problemem w krajach uprzemysłowionych. Zmniejszenie ekspozycji na hałas nastąpiło poprzez realizację programu zapobiegania utracie słuchu, zwłaszcza poprzez korzystanie z ochronników słuchu, tłumiących hałas (28).

Dużą liczbę przypadków w województwie: wielkopolskim, zachodniopomorskim, małopolskim, świętokrzyskim, dolnośląskim i kujawsko-pomorskim można przypisać szerokiej infrastrukturze w/w województw. Analogicznie niewielka liczba przypadków w województwie podlaskim, warmińsko-mazurskim nie budzi zdziwienia z uwagi na niewielką liczbę zakładów przemysłowych tych województw. Niepokojące są natomiast wyniki z województwa łódzkiego odznaczającego się dużą liczbą osób zatrudnionych w przemyśle. Jednak takie wyniki przypisać można niedoszacowaniu chorób zawodowych podyktowanemu przypuszczalnie obawą pracowników narażonych na hałas o utratę zatrudnienia lub przeniesieniem na mniej opłacalne stanowisko pracy (Ryc. 2).

Utrzymująca się w Polsce tendencja zmniejszającej się liczby chorób zawodowego uszkodzenia słuchu wiąże się też z upadłością poszczególnych zakładów przemysłowych w sektorach PKD, w których pracownicy byli narażeni na ponadnormatywny hałas (29). W województwie podkarpackim pracownicy powiatów tzw. „uprzemysłowionych” odznaczali się znaczną liczbą przypadków ubytku słuchu (stalowowolski, krośnieński i rzeszowski). Zwiększona liczba przypadków zawodowego uszkodzenia słuchu w powiecie przemyskim ma swoje wyttumaczenie w specyfice gospodarczej tego powiatu, w którym rozwija się przemysł drzewny stwarzający ryzyko zwiększonego narażenia na hałas. Niewielką liczbę przypadków zawodowego uszkodzenia słuchu u pracowników w pozostałych powiatach przypisać można prawdopodobnie zjawisku niedoszacowaniu chorób zawodowych. Ponadto nieznaczna liczba przypadków wynika z działań prewencyjnych służb bezpieczeństwa i higieny pracy oraz organów ich nadzorujących takich jak Państwowa Inspekcja Sanitarna i Państwowa Inspekcja Pracy (Ryc. 3).

\section{WNIOSKI}

1. Od 2010 roku obserwuje się w Polsce stałe zmniejszanie się liczby przypadków zawodowego uszkodzenia słuchu.

2. Najczęściej choroba ta jest rozpoznawana u mężczyzn po 60. roku życia, związanych zawodowo z górnictwem i przemysłem ciężkim - maszynowym, hutnictwem, środkami transportu.

3. Województwami o największej bezwzględnej liczbie stwierdzonych uszkodzeń słuchu o etiologii zawodowej są: śląski i pomorski. 
3. Warunki pracy w 2008-2017. Główny Urząd Statystyczny. Warszawa 2009-2018.

4. Świątkowska B., Hanke W., Szeszenia-Dąbrowska. Choroby zawodowe. Wydaw. Instytut Medycyny Pracy, Łódź 2018: 16-65.

5. Pawlaczyk-Łuszczyńska M. Kontrola narażenia na hałas W: Minimalizowanie ryzyka uszkodzenia słuchu w miejscu pracy. Poradnik dla pracowników BHP, PIS, PIP, pracodawców i pracowników, red. M. Pawlaczyk-Łuszczyńska, Wydaw. Instytut Medycyny Pracy, Łódź 2010: 13-40.

6. Pawlaczyk-Łuszczyńska M., Zamojska M., Dudarewicz A. i in.. Działania minimalizujące skutki wpływu hałasu na narząd słuchu. W: Profilaktyka zawodowych uszkodzeń słuchu. Poradnik dla lekarzy, red. M. Śliwińska-Kowalska Wydaw. Instytut Medycyny Pracy, Łódź 2010: 45 .

7. Śliwińska-Kowalska M. Mechanizmy uszkodzenia słuchu przez hałas W: Profilaktyka zawodowych uszkodzeń słuchu. Poradnik dla lekarzy, red. M. Śliwińska-Kowalska Wydaw. Instytut Medycyny Pracy, Łódź 2010: 5.

8. Miterska M. Analiza narażenia pracowników górnictwa na trwałe uszkodzenia słuchu. Prace Naukowe GIG Górnictwo i Środowisko 2009; 4: 55-63.

9. Rozporządzenie Ministra Rodziny, Pracy i Polityki Społecznej z dnia 12 czerwca 2018 r. w sprawie najwyższych dopuszczalnych stężeń i natężeń czynników szkodliwych dla zdrowia w środowisku pracy. Dz.U. z 2018, poz. 1286.

10. Rozporządzenie Ministra Gospodarki i Pracy z dnia 5 sierpnia 2005 r. w sprawie bezpieczeństwa i higieny pracy przy pracach związanych z narażeniem na hałas lub drgania mechaniczne. Dz.U. z 2005, nr 157, poz. 1318.

11. Dyrektywa 2003/10/WE Parlamentu Europejskiego i Rady z dnia 6 lutego 2003 r. w sprawie minimalnych wymagań w zakresie ochrony zdrowia i bezpieczeństwa dotyczących narażenia pracowników na ryzyko spowodowane czynnikami fizycznymi (hałasem).

12. Pawlaczyk-Łuszczyńska M., Zamojska M., Dudarewicz A. i in. Działania minimalizujące skutki wpływu hałasu na narząd słuchu W: Profilaktyka zawodowych uszkodzeń słuchu. Poradnik dla lekarzy, red. Śliwińska-Kowalska M. Wydaw. Instytut Medycyny Pracy, Łódź 2010: 32-46.

13. Śliwińska-Kowalska M. Obraz kliniczny zawodowego uszkodzenia słuchu W: Profilaktyka zawodowych uszkodzeń słuchu. Poradnik dla lekarzy, red. Śliwińska-Kowalska M. Wydaw. Instytut Medycyny Pracy, Łódź 2010: 15-24.

14. Sprawozdanie Podkarpackiego Państwowego Wojewódzkiego Inspektora Sanitarnego MZ 50 za 20082017, Rzeszów 2009-2018.

15. Szeszenia-Dąbrowska N., Wilczyńska U., Sobala W. Choroby zawodowe w Polsce w 2008 r., Centralny Rejestr Chorób Zawodowych, Wydaw. Instytut Medycyny Pracy, Łódź 2009: 17-131.

16. Szeszenia-Dąbrowska N., Wilczyńska U., Sobala W. Choroby zawodowe w Polsce w 2009 r., Centralny Rejestr Chorób Zawodowych, Wydaw. Instytut Medycyny Pracy, Łódź 2010: 20-131.
4. Częstość rozpoznawania zawodowego uszkodzenia słuchu w województwie podkarpackim jest niewielka. W latach 2008-2017 stwierdzono 74 przypadków tej choroby.

5. W województwie podkarpackim powiatami o najwyższej liczbie przypadków zawodowego uszkodzenia słuchu są: stalowowolski (przemysł hutniczy), krośnieński, rzeszowski i przemyski (przemysł hutniczy i drzewny).

6. Zróżnicowanie występowania zawodowego uszkodzenia słuchu w województwie podkarpackim wynika z infrastruktury województwa. W większości powiatów brak jest dużych zakładów przemysłowych, w których występuje zwiększona ekspozycja na hałas.

17. Szeszenia-Dąbrowska N., Wilczyńska U., Sobala W. Choroby zawodowe w Polsce w 2010 r., Centralny Rejestr Chorób Zawodowych, Wydaw. Instytut Medycyny Pracy, Łódź 2011: 15-102.

18. Szeszenia-Dąbrowska N., Wilczyńska U., Sobala W. Choroby zawodowe w Polsce w 2011 r., Centralny Rejestr Chorób Zawodowych, Wydaw. Instytut Medycyny Pracy, Łódź 2012: 15-83.

19. Szeszenia-Dąbrowska N., Wilczyńska U., Sobala W. Choroby zawodowe w Polsce w 2012 r., Centralny Rejestr Chorób Zawodowych, Wydaw. Instytut Medycyny Pracy, Łódź 2013: 15-83.

20. Szeszenia-Dąbrowska N., Wilczyńska U., Sobala W. Choroby zawodowe w Polsce w 2013 r., Centralny Rejestr Chorób Zawodowych, Wydaw. Instytut Medycyny Pracy, Łódź 2014: 15-81.

21. Szeszenia-Dąbrowska N., Wilczyńska U., Sobala W. Choroby zawodowe w Polsce w 2014 r., Centralny Rejestr Chorób Zawodowych, Wydaw. Instytut Medycyny Pracy, Łódź 2015: 15-71.

22. Szeszenia-Dąbrowska N., Wilczyńska U., Sobala W. Choroby zawodowe w Polsce w 2015 r., Centralny Rejestr Chorób Zawodowych, Wydaw. Instytut Medycyny Pracy, Łódź 2016: 15-67.

23. Szeszenia-Dąbrowska N., Wilczyńska U., Sobala W. Choroby zawodowe w Polsce w 2016 r., Centralny Rejestr Chorób Zawodowych, Wydaw. Instytut Medycyny Pracy, Łódź 2017: 15-68.

24. Rozporządzenie Rady Ministrów z dnia 24 grudnia 2007 r. w sprawie Polskiej Klasyfikacji Działalności (PKD) Dz.U. z 2007 r., nr 251, poz. 1885 z późn. zm.

25. Agarwal G., Nagpure P.S., Gadge S.V. Noise Induced Hearing Loss in Steel Factory Workers. Int J Occup Safety Health 2015; 4(2): 34-43.

26. Rocznik statystyczny pracy 2010-2017. Główny Urząd Statystyczny. Warszawa 2010-2017.

27. Wiśniowski R. Ryzyko narażenia na hałas w górnictwie węgla kamiennego i dobór środków ochrony indywidualnej słuchu. Przegląd Górniczy 2014; 51(12): 51 
28. Rangkooy H.A, Rashnuodi P, Salehy M.M.A, et al. Evaluation of Noise - Jnduced Hearing Loss on the Workers of one of the Ahvaz Steel Companies. Jundishapur J Health Sci 2018; 10(1): 3-5.

29. Verbeek J.H., Kateman E., Morata T.C, et al. Interventions to prevent occupational noise - induced hearing loss: A Cochrane systematic review. Int J Audiol 2014; 53: 84-96.

30. Guzek W J, Sułkowski W J. Zawodowe uszkodzenie słuchu: Nowe zasady orzecznicze. Med. Pracy 2002; 53(5): 387-388.
Received: 28.08.2018

Accepted for publication: 4.12 .2018

Otrzymano: 6.09.2018 r.

Zaakceptowano do publikacji: 21.01.2019 r.

\section{Address for correspondence:}

Adres do korespondencji:

agnieszka.rybka@wsse.rzeszow.pl 